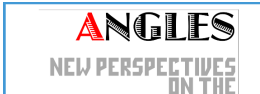
ANELOPHONE WORLD

\section{Angles}

New Perspectives on the Anglophone World

3 | 2016

Angles and limes

\title{
Is Equal Protection a Language Game?
}

\section{Anne-Marie O'Connell}

\section{(2) OpenEdition}

\section{Journals}

\section{Electronic version}

URL: https://journals.openedition.org/angles/1748

DOI: $10.4000 /$ angles. 1748

ISSN: 2274-2042

\section{Publisher}

Société des Anglicistes de l'Enseignement Supérieur

\section{Electronic reference}

Anne-Marie O'Connell, "Is Equal Protection a Language Game?", Angles [Online], 3 | 2016, Online since 01 November 2016, connection on 07 June 2022. URL: http://journals.openedition.org/angles/1748 ; DOI: https://doi.org/10.4000/angles. 1748

This text was automatically generated on 7 June 2022.

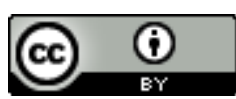

Angles est mise à disposition selon les termes de la Licence Creative Commons Attribution 4.0 International. 


\title{
Is Equal Protection a Language Game?
}

\author{
Anne-Marie O'Connell
}

\section{Introduction}

1 The role of law is to regulate interactions among the members of a given polity, and between these members, their governments and their institutions. Parallel to the legal acts that contribute to the evolution of society, be they parliamentary decisions, court rulings or administrative orders, the law has developed a language of its own with its concepts and procedural rules. In the context of judicial review involving the US Supreme Court, interpretation is associated with the role of the Justices in deciding which meaning to give to a constitutional clause in relation to a specific case within the jurisdiction of the Court. Discussions concern points of doctrine, and there is no clear consensus among jurists as to the origin of the meaning of the constitutional text, nor do they all agree about the role the Supreme Court Justices should play in the process: does meaning originate in the minds of the Founders? Is it only present in the words of the Constitution? Should judges restrain their interpretive powers to the literal elucidation of the text, or should they rather be more active and adapt the constitutional text to current social criteria? None of those preoccupations are of immediate concern to a philosopher of language. Even though meaning is a major issue, the legal approach does not fit into the categories developed in the field of analytical philosophy, which would rather focus its efforts on eliciting the emergence of meaning as the result of interactions between a reference, ${ }^{1}$ verbal statements, ${ }^{2}$ and those speakers involved in the speech act. But this is the arena in which those apparently diverging interests can meet and interact.

2 The purpose of the present contribution is to provide an insight into the semantics of the Equal Protection Clause of the Fourteenth Amendment to the US Constitution from a philosophical viewpoint. This clause has been at the root of many controversies among jurists and those directly affected by the Supreme Court's decisions in the 
course of the United States' constitutional history, because of its extraordinary and farreaching influence on society and politics. It goes as follows:

All persons born or naturalized in the United States, and subject to the jurisdiction thereof, are citizens of the United States and of the State wherein they reside. No State shall make or enforce any law which shall abridge the privileges or immunities of citizens of the United States; nor shall any State deprive any person of life, liberty, or property, without due process of law; nor deny to any person within its jurisdiction the equal protection of the laws. (1 $14^{\text {th }}$ Amendment to the US Constitution, Section 1)

Since its aim is to prohibit discrimination by state action, the disputes have focused on the meaning of equality among those under state jurisdiction. Since its ratification by Congress in 1868, the Fourteenth Amendment's Equal Protection Clause has fostered a variety of divisive issues, like the legality of racial segregation, of mixed race or singlesex marriage, of the treatment of non-nationals, of affirmative action measures in education and contracting, to name but a few of the issues that were absent from the congressional debates that preceded the ratification of the Amendment. Due to the normative nature of law, those issues not only concern legal interpretation itself, but also people and groups sharing the same interests. Moreover, equality, in itself a very broad concept to define, has been subject to so many different interpretations that the Supreme Court has often found itself in the eye of social, political and moral controversy whenever it had to decide on equal protection issues, not to mention the legal disputations its rulings have triggered in the world of legal scholars, let alone among the Justices themselves. The issue that will be discussed in the present contribution concerns the nature of the language of the law in connection with its interpretation, with reference to Ludwig Wittgenstein's theory of the language game developed in his Philosophical Investigations (1958). Many scholars have focused their attention on one particular aspect of his work, namely "rule following" in connection with the possibility of attributing meaning to law and to the rules of interpretation (Markell 805-810, Finkelstein). Whether there is such a thing as "legal truth" has been the subject of many academic discussions, notably between the Legal Realists and the Critical Legal Scholars. Both currents have elaborated contrasting theories on the relation between rules of interpretation and the law, which constitutes their verbal reference. The former have construed Wittgenstein's treatment of rule-following as evidence that legal rules are fundamentally indeterminate (Arulanantham). The latter, dubbed the Anti-Realist current, argue that Wittgenstein never stated that language was indeterminate, but that our assumptions about how it operated were flawed at best, or even nonsensical (Bix), and that Wittgenstein's views do not fully apply to the field of legal interpretation.

5 My argument offers a somewhat different perspective on the subject. I will argue that it is possible to consider the language of law as what Wittgenstein calls a language game (1958: 23) ${ }^{3}$ while contending that language being self-referential, the meaning of law can find an extra-linguistic reference in the concept of time. But what bridges the conceptual gap between the self-enclosed world of the language game and the world of history lies in a property of language that has hitherto been neglected: its metaphoric aspect. If, indeed, the meaning of legal interpretation can be approached via the exploration of its grammar, its rules, that have produced contrasted and sometimes ambiguous results as expressed in the Court's decisions involving the Equal Protection Clause, some interpretations cannot be fully understood without taking the creativity 
of language into consideration. Because words do not point to a unique reference, and because resorting to images and synonyms can bring additional knowledge about the world thus designated (Frege), ${ }^{4}$ the language of law develops into linguistic variations leading to the creation of different concepts and different outcomes within the compass of legal interpretation, the more so as the logical structure of reasoning is based on analogy. The latter, in turn, operates on the grounds that elements from cases can be used in other instances, but, ultimately, it can only refer to the constitutional norm, which is based on an initial statement about the world as it is.

However, such a notion cannot be confined to a flat chronological backdrop against which history unfolds, but should be seen as the substance that shapes the identity and the memory of groups that have been differently affected by legal decisions, and judges are part of that very process. More specifically, our aim is to show how the constitutional clause, as interpreted by the US Supreme Court, is structured in relation to the two following aspects: first, its meaning and how it emerges from the statement made by the clause and, secondly, its complex relation with time, a concept that covers several dimensions, such as history, memory, or hermeneutics. In that perspective we will follow the detailed study conducted by French philosopher Paul Ricœur (1975, 1983, 1985). The meaning of legal interpretation can also be approached via the exploration of, in Wittgenstein's words, its grammar and rules. For the sake of consistency, the analysis will be confined to the issue of racial segregation, with particular emphasis on cases such as Plessy v. Ferguson (1896), Brown v. Board. of Education of Topeka (1954) and Regents of the University of California v. Bakke (1978).

\section{Structure of the language game}

\section{Definition of "rule" and "reference"}

7 The piecemeal definition given by Wittgenstein of language games is rather disconcerting at first because he devotes many paragraphs to the impossibility of anyone knowing what the expression actually means, since it cannot be reduced to what is normally referred to as concepts; this indeterminacy encompasses all the constitutive elements of the language game, including rules, common understanding of those rules among the players, intended meaning, and the very idea of meaning itself, as exemplified in the following extracts: "How should we explain to someone what a game is? [...] We do not know the boundaries because none have been drawn. To repeat, we can draw a boundary-for a special purpose. Does it take that to make the concept usable? Not at all" (1958 33)-he also insists on the inadequacy of logical categories in defining games (ibid. 33, 34, 35). On language, he states:

You talk about all sorts of language games, but have nowhere said what the essence of a language-game, hence of language, is: what is common to all these activities, and what makes them into language or parts of language [...] And this is true. Instead of producing something common to all that we call language, I am saying that these phenomena have no one thing in common which makes us use the same word for all (ibid. 31).

8 He then proceeds to give a paradoxical definition of rules:

What do I call "the rule by which he proceeds"? -The hypothesis that satisfactorily describes his use of words, which we observe; or the rules which he looks up when he uses signs; or the one which he gives us in reply if we ask him what his rule is? - 
But what if observation does not enable us to see any clear rule, and the question brings none to light? [...] What meaning is the expression "the rule by which he proceeds" supposed to have left to it here? (ibid. 38. $)^{5}$

of the common understanding of rules he says:

But what does the picture of a leaf look like when it does not show us any particular shape, but what is common to all shapes of leaf? Which shape is the 'sample in my mind' of the colour green-the sample of what is common to all shades of green? (ibid. 34)

Must I know whether I understand a word? Don't I also sometimes imagine myself to understand a word [...] and then realize that I did not understand it? (ibid. 39) The fundamental fact here is that we lay down rules, a technique, for a game, and that then when we follow the rules, things do not turn out as we had assumed. [...] It throws light on our concept of meaning ${ }^{6}$ something. For in those cases things turn out otherwise than we had meant, foreseen. That is just what we say when, for example, a contradiction appears: 'I didn't mean it like that' (ibid. 50; see also id. at 39,53 and 54).

This state of utter uncertainty regarding the rules that govern the conduct of speakers stands in jarring contrast with the requirements of legal adjudication and constitutional interpretation, where the predictability of court decisions and the clarity of rule-following are essential. In fact, language use is made up of an infinite number of language games and rule-following is synonymous with experience. Legal interpretation derives from a careful examination of case law, of precedents, and this close scrutiny yields two conclusions: first, that it forms a cohesive continuum and, secondly, that there is a substantive congruence between the constitutional text and the overall series of derived decisions, something that Ronald Dworkin dubbed the chain novel qualified by the criterion of fit (229-32) ${ }^{7}$. In this language game, the reference, that which attributes a truth value to a statement, is not situated in an extra-linguistic reality, and no real life, concrete fact will be the measure of its truth or falsity; in fact, the ultimate reference is verbal, because it is the constitutional text itself. Since Marbury $v$. Madison was decided in $1803,{ }^{8}$ the Constitution has been considered as the supreme law of the land as far as the duty of courts in matters of judicial review is concerned. The logical consequence of that statement is that constitutional adjudication only addresses two questions, the first one being "what does that text mean?" (Kay 706), and the second: "how does it mean it?"

As a preamble, let us make two remarks: first, the reference in the interpretive language game being textual, and not factual, there is no reason why the Equal Protection Clause should not be considered on a par with texts of a different kind. After all, a textual commentary can only be carried out on the assumption that there is a common, reasonable agreement on the meaning of its words and sentences (Fiss 742-43), ${ }^{9}$ albeit admitting a leeway in the manner in which meaning is to be assessed. This leads us to the second remark, namely that language exceeds explication, which can only be inadequate and mediate if we follow Wittgenstein when he argues that meaning is experienced more in language use than in conceptualization. Thus, theories that aim to assign meaning to a particular location are doomed to fail. If one adopts the mentalist's view of the original intent as the source and location of the meaning of the Equal Protection Clause, we negate the possibility for the Constitution to mean anything outside this specific context of utterance. One might wonder what relevance it would have centuries after its ratification, because one effect would be to deny History any power and influence over societies. Besides, the Founders themselves never 
laid out a particular rule that would govern the interpretive conduct of judges. Likewise, it is far from certain that rules of interpretation that focus on the meaning of words avoid such pitfalls. Constitutional meaning can be seen as continuous because it has acquired a time-honored definition through history, or affirmed with reference to what dictionaries or thesauruses have determined it should be. Additionally, making social or historical context the sole criterion in matters of interpretation would restore the correlation between objects of the world and language: if that was completely the case, then why would the constitutional text be the source of all interpretations, if it was not endowed with some permanent meaning of its own? That is the reason why Wittgenstein would say that there is no such thing as a fixed rule, because "we make rules as we go along" (1958: 38$)^{10}$ and that ascribing meaning by referring to another word, and not to a fact, only demonstrates the arbitrariness of the process, and this is logically nonsensical (ibid. 7). He did stress that rules exist, but that they do not follow the logical pattern ascribed to them because these are mere reconstructions, mere fictions. However, there is no reason to doubt the existence of rules, and of meaning; but they rarely take the well-trodden paths described by philosophers. In fact, intellectual categories have rather obscured the issue, by separating and labeling texts according to type or subject-matter, as was recommended by Aristotle. These were the earliest examples of this theory of language.

12 One particular feature of this classification is to restrict linguistic structures and figures of speech to specific domains, like seeing metaphor as restricted to the domain of literature. Roman Jakobson attributes six functions to language (62) and, according to him, metaphor expresses the way in which language is used for its own sake and for aesthetic purposes. But it can be equally considered as cognitive and informative. Frege, albeit in a theory that equates logic with perfection in language, admits that the planet Venus can be equally designated by the expressions "Morning Star" or "Evening Star": the reference remains identical (the planet), and is semantic in nature, but meanings, expressed by signs, differ from each other. Yet, it is not impossible to designate different semantic contents with one given sign (or word) in different texts: this is the case with the word person in the Equal Protection Clause, since it came to mean different things, based on what can be called the metaphoric substance of language. To illustrate this view, reference will be made to French philosopher Paul Ricœur, who devoted an in-depth analysis to the metaphoric nature of language in $L a$ Métaphore vive (1975), translated into English in 1977 as The Rule of Metaphor. ${ }^{11}$ One of the central points developed in this opus is that metaphor is not just a linguistic tool fulfilling a poetic or a rhetorical function in speech and discourse, but it is crucial in the emergence of meaning, while redefining our concept of truth along other lines: it should not be seen as partaking of logical coherence and empiric verification only. Language, through what he calls metaphoricity, can effectively create a new facet of reality that integrates a cognitive dimension distinct from reference to the objects and states of affairs. Moving from the semiotic dimension of meaning and metaphor (the one that only considers the word as the unit of meaning) to semantics (according to which the meaning of metaphor encompasses the whole sentence) to hermeneutics (an interpretation that attributes meaning to a metaphor sustained throughout a whole text, be it fictional or philosophical), the metaphor transcends and creates reality and cannot be dissociated from the thought process. Within the boundaries of a given language game, metaphoricity expands the possibilities of interpreting facts and textual 
references in a creative, yet normative manner, a process that may open perspectives in the field of constitutional adjudication.

\section{The metaphor of the "person"}

13 This word is emblematic of the interpretive disputes that have arisen in connection with the Equal Protection Clause, because the notion of corporate personhood was the result of the gradual metaphorization of the language of law, which provides an insight into the definition and scope of the Equal Protection Clause while allowing the creation of applications of the term to other, subsidiary contexts (Ricœur 1975: 112-14). When the Fourteenth Amendment was ratified, it was clear in the minds of those who pressed for its adoption that a person was a natural person and, for many of them, that the Amendment aimed to protect the newly-freed slaves from future disenfranchisement. Since then, several appeals have been heard by the Supreme Court as to the constitutionality of the doctrine of corporate personhood and the desirability of maintaining corporations under state legislative control, a point illustrated in Darthmouth Coll. v. Woodward (1819) where the Supreme Court limited the power of government to control corporations whose existence was "found" in the Constitution. In Paul v. Virginia (1868) the Court ruled that corporations were not citizens under Article IV, section 2 of the Constitution; in The Slaughterhouse Cases (1873) corporations were denied the protection of the Civil War Amendments; while not deciding on corporate personhood per se, the Court reaffirmed in 1877, in Munn v. Illinois (1877) and later in the Railroad Tax Cases (1882) ${ }^{12}$ that the Fourteenth Amendment could not protect corporations from State law. The turning point was Santa Clara County v. So. Pacific Railroad (1886) when the Chief Justice, although the issue did not concern personhood, expressed his opinion in favor of granting it to corporations, which was ruled constitutional in 1889 in Minneapolis \& St. Louis Railroad v. Beckwith. Not only has corporate personhood a history in which ideology and economic interests were intermingled, but it also came to be accepted by the Court, in connection with the Fourteenth Amendment, because of the structure of corporations and its analogy with individuals and citizens. The mechanism by which an entity acquires characteristics and rights normally attributed to human beings consists in extracting features from the legal semantic field of the natural person and analogically applying them to corporations (Ricœur 1975: 258). Metaphorically, corporations can be identified in the same way as individuals, via documentation that follows similar paths and has similar functions. If a corporation can be defined as property held in common by a group of people while forming a separate identity, it can live a life of its own and is free to interact with business partners and institutions by means of contracts, just as natural persons do. The latter undergo a process of progressive abstraction of their most fundamental characteristics, and thus become general entities that can, in turn, be associated with different semantic contents; the process is linguistic, not logical, and this explains why meaning fluctuates with time and circumstances, without giving the impression that some rule of consistency has ever been violated. Moreover, the legal entity, which represents the common pursuit of a group of shareholders, is the semantic image of that collectivity and comes to embody it in the same way as a metonymy would (ibid. 256). The convergence between metonymy (one element that designates the whole) and metaphor (the semantic analogy that keeps the structure together) provides the linguistic and semantic foundation for judges to grant equal protection 
and other rights to corporations, even if the outcome is not always widely sustained. ${ }^{13}$ Wittgenstein would explain the convergence between natural and corporate persons as the expression of a "family resemblance," in which there is no clear boundary between words and concepts, so that semantic glides actually occur and polysemy generates the metaphor (1953: 32). But the semantic creativity of language is also sustained by the manner in which courts build up doctrines and legal concepts, more particularly with reference to binding precedents. Indeed, as the underlying logical structure is based on analogy, it enables judges to apply some findings in relation to a specific case to another instance, whose subject matter is unrelated in content, and similar in purpose. Thus, the definition and scope of Equal Protection can depart from its originally narrower ambit to encompass a much wider range of applications.

\section{The analogical chain of interpretation}

This interpretive path is provided by the manner in which specific cases can be generalized to whole areas of the law, and the double process of gradual racial segregation and, conversely, its progressive abolition in all its forms, is a case in point. In Plessy v. Ferguson (1896), the question whether state legislation imposing segregated facilities in public transport was constitutional was decided, among other considerations, in relation to precedents involving school segregation (544) and interracial marriage (545), while distinguishing the case under review from other appeals directly concerning public means of conveyance, because the latter involved interstate commerce (546) or a state ban on segregated transport (546). The only case involving transport that the Court considered as a valid precedent differed in the facts but shared the same legal issue (547). Thus the chain of reasoning hinges on both form and content, but none of those features need belong to similar cases and circumstances; what matters most is the way in which the Court reaches its decision, and if segregation is constitutional for schools or marriage, it can be so for public transport. This narrow path nevertheless provided state legislatures with the power to generalize racial segregation to other areas of social life, based on the same principle of the chain of analogies that support the metaphor of race. Likewise, in Bolling v. Sharpe (1954), the Court resorted to the same kind of device to reverse Plessy, when it stated that " $(\mathrm{t})$ he Fifth Amendment, which is applicable in the District of Columbia, does not contain an equal protection clause as does the Fourteenth Amendment which applies only to the states. But the concepts of equal protection and due process, both stemming from our American ideal of fairness, are not mutually exclusive." And, although Brown v. Board of Education, decided on the same day, concerns racial segregation in state schools, Justice Warren concluded on the analogy between both cases by stating that "it would be unthinkable that the same Constitution would impose a lesser duty on the Federal Government." Many scholarly disputes have arisen as to the legal solidity of those arguments, but these controversies illustrate another aspect of legal interpretation, namely that rules may exist, but that they tend not to produce identical results, something that Wittgenstein expressed in one of his sporting metaphors: "but no more are there any rules for how high one throws the ball in tennis, or how hard; yet tennis is a game for all that and has rules too" (1958: 32 ).

15 What emerges from such considerations is that rules, which are part and parcel of the interpretive language game, are subject to other influences, such as political opinions or social and philosophical views that may explain the differences in results, as well as 
the plurality of opinions expressed in court decisions. There are instances in which opposite viewpoints rest on the variations in meaning of a particularly important term, which can yield diverging results, depending on which solution is adopted. Thus, in Plessy, Justice Harlan, quoting Strauder v. West Virginia (1880), dissents from the majority opinion on most points, and particularly emphasizes the semantic gap that separates his understanding of equal protection from that of the other Justices': "We also said: 'The words of the amendment, it is true, are prohibitory, but they contain a necessary implication of a positive immunity or right, most valuable to the colored race"' (Plessy 556, emphasis added). Whether or not necessity is involved in the process, it remains that meaning, when attributed to a word or a noun or a name, is floating, while it does not prevent propositions from being experienced as true or false, or the product of experience from participating in the future definition of a concept (Wittgenstein, 1958, 36). Ultimately, there is no way to assess the abstract superiority of one argument over another (Markell), which probably explains the persistence of controversies in matters of constitutional adjudication when it comes to Supreme Court rulings. But this discussion should not be restricted to internal debates in interpretation; if meaning is intrinsically experienced, then the social dimension of Equal Protection cases and decisions offers the perfect ground for the confrontation of different views of the constitutional language game. One element that structures and differentiates the perceived implications of the Fourteenth Amendment by the various social actors involved in the game is time in its hermeneutic dimension. ${ }^{14}$

\section{The hermeneutic role of time in the adjudicative language game}

16 So far, we have come to the conclusion that what sustains the coherence of interpretive rules in the legal language game is metaphoric in nature, which may explain why the existence of logically-structured rules (which maintain the cohesion of the system) may foster creativity. For Ricœur, metaphoricity belongs to discourse, which is the expression of the opinions and feelings of a conscious subject who lives in time. The paradox of time is that it is perceived as a whole, and yet, there is a clear dichotomy between cosmic, calendar time and the time of perception and experience (which he calls phenomenological time), and, within the latter, another rift between the past, the present and the future in the conscience of the subject (Ricœur 1983: 21-65) or, more aptly perhaps, the human being, endowed with existence. Making sense of this aporetic structure of time necessitates the creation of some narrative that puts time and experience in perspective: telling a story is already some sort of explication of experience, of existence and of the essence of time. Ricœur focuses his analysis on the relation between time and historical narratives, which he then closely connects to fiction. In both cases, time becomes the subject of the narrative; historians have long believed that history consists in the logical construction of the past, with a view to providing a probable explication of the course of past events in a predictive perspective called the "nomologist approach" (Ricœur 1983: 204-05) while novelists provide us with a description of history, as well as with a specific, non-neutral viewpoint. Both standpoints are not, however, incompatible, because both tend to create narratives. The historical narrative, in its relation to time, is an attempt to come to terms with such issues as personal identity, finality and the meaning of existence. The narrative 
construction of history resorts to three types of features (Ricœur 1985: 189): cosmological time (the movement of planets, the cycle of seasons), calendar time (which represents the succession of years as well as the repetition of events and commemorations), and experienced time. On the other hand, the Self experiences its existence in the presence of others who have a commonality of interests and share some common features (Ricœur 1985: 198-208). Time enables humans to think of history in terms of continuity between past, present and future generations, a process fueled by the gradual collection of archives, documents and traces (Ricœur 1985: 215-24). Such characteristics are applicable to all human groups and social activities, among which one may count legal interpretation. But memory is also a matter of point of view and perspective, and judicial review is also conditioned by history; this has generated conflicts, especially with respect to the Equal Protection Clause for two reasons: first, because the manner in which the Court construes time differs from the perception of the actors that are directly concerned by the ruling (i.e. the parties to the case), and secondly, because the issues associated with the Fourteenth Amendment are not only a matter of law and legal reasoning, but of justice, which partakes of the sphere of ethics. This concept refers to the substantive aspect of law and is more traditionally divided between corrective and distributive justice. These two elements play an important part in the debate over affirmative action, as illustrated by the Supreme Court's decision in the Bakke case, which also reflects on the hierarchy of values in Equal Protection embodied by the three-tier scrutiny system that places race as its leading and ambiguous paradigm.

\section{The Supreme Court's narrative of Equal Protection}

17 In his Bakke opinion, Justice Powell recapitulates the position of the Supreme Court regarding the meaning of Equal Protection and its relative importance within the interpretation of the Fourteenth Amendment (291-99). He begins with a historical overview of "the perception of racial and ethnic distinctions," which he deems "rooted in our Nation's constitutional and demographic history." He then proceeds to construe the Court's view of the Fourteenth Amendment as changing, and the importance of the Equal Protection Clause as varying in the course of US history for the benefit of the Due Process Clause, a phenomenon mirrored in case law. He sees the fluctuation in meaning and scope of the Amendment as the result of an antagonism between these two clauses, one striving to protect "the newly-made freeman and citizen from the oppression of those who had formerly exercised dominion over him" (291), while the other one had been repeatedly used to expand the meaning of property via the doctrine of so-called "substantive due process" (291-92). ${ }^{15}$ Parallel to this legal dichotomy, which we may assume he considers to be an error (an opinion reflected in his choice of words "relegated," "desuetude," "displaced," "genuine measure of vitality"), Justice Powell develops his view that the demographic landscape of the United States had changed (292), and that this is something that would justify a new consideration of the Equal Protection Clause. His aim is to show that the original meaning of the Equal Protection Clause has been broadened to include all minorities (292). ${ }^{16}$ But his reasoning goes beyond the statement that the United States is a nation of immigrants that have equal claims to the protection of minorities against state discrimination; he does away with the very notion of majority by supporting the view that it can be replaced with the notion of group alliances against another, and underlines that such alliances may be 
circumstantial and changing, ${ }^{17}$ and that these changes depend more on social fluctuations than on deliberate policies. Having removed the racial sting against one particular class of citizens from his analysis of the scope of Equal Protection, he then moves on to argue that the Amendment, whose reach is universal (293), ${ }^{18}$ can only be construed as applying to individuals, not groups (296), ${ }^{19}$ by virtue of his fluctuating majority theory. Accordingly, yielding to real, but circumstantial cases, would deprive the Constitution of any coherent and universal application, which would run counter to the very exercise of judicial review (297). ${ }^{20}$ This line of interpretation reads like an historical narrative of the nomological kind; it is descriptive of an interpretive process, it generalizes cases to their most abstract aspect and adopts a universal vision of persons, citizens, individuals. These words point to a subtext that contains the essential characteristics of human nature as ideals, in the same way that a mathematician would deal with symbols. Similarly, groups are presented as the mere aggregation of persons sharing identical interests and characteristics; they are abstract, anonymous, and contrast with individuals only to say that the law knows the latter, not the former. Sociological changes are equated with demography, a reference that has an objective value in the eye of the judge because it is a science, and any fluctuation in that domain is an object, a fact in relation to which a proposition can say something descriptive, according to Wittgenstein's Tractatus Logico-Philosophicus. In that sense, these fluctuations mean something. ${ }^{21}$ In a world defined as "everything that is the case [...] the totality of facts, not things [...] determined by the facts, and by these being all the facts" (ibid. 31), the language of propositions makes sense if they adequately (that is, by using the correct logical symbols) describe events and objects in the world of reference, if they are analytical (or tautological) and thus, devoid of any cognitive content (ibid. 155); on the other hand, a language that would form pseudo-propositions, like most ethical or philosophical propositions, would not make any sense, because it would refer to language itself, not to facts or events: in Wittgenstein's Tractatus, there is no such thing as meta-language ("Whereof one cannot speak, thereof one must be silent" [ibid. 189]). However, a proposition can show what it cannot say, which is the case when it is true, and this includes understanding, as well as anything that lies beyond the boundaries of the world; saying and showing are mutually exclusive even if they somehow coexist in propositions. Thus the judgment in Bakke strives to restrict its scope to following the rules of the legal language game, and rejects other sociological or ethical considerations outside its boundaries. Wittgenstein states in a famous letter to Ludwig von Ficker that the meaning of his Tractatus was ethical, but that ethics constituted its unwritten part (McGuinness 287; Engelmann 143-44). What is at stake in the Bakke ruling is precisely the ethical issue of justice-indeed, this case evidences the conflict between two language games. Opposite the language of law is the language game of a group, a community that has been shaped by history as well as by a collective, shared memory around the central paradigm of racial discrimination. In fact, in a manner similar to a Wittgensteinian proposition, the court ruling in Bakke says something about the rules of the language game and shows how the paradigm of race has deeply shaped the narrative of constitutional interpretation. It is particularly clear in the manner in which the Court has devised a differential system of scrutiny in relation to cases involving the Equal Protection Clause, which will be the focus of the next part. 


\section{The three-tiered standard of scrutiny}

18 In the course of legal interpretation, the Court's attitude toward government discrimination has changed, and the case of Carolene Products (1938)22 and its now famous "Footnote 4" has been hailed a landmark decision in that respect. ${ }^{23}$ It introduces into the review process the idea that there are different types of discrimination, and that some, being more serious than others, would demand stronger accountability of the legislature or government to justify it. The Footnote includes all the provisions of the Bill of Rights in its scope, as well as the Fourteenth Amendment within a stricter standard of scrutiny. Thus, any legislative decision that would, on its face, treat groups differently on the basis of race should be considered unconstitutional unless the government justifies its action by proving it would fulfill the aims and objectives of the Fourteenth Amendment. While it is easy to understand why the Court has introduced a scale in the standards of judicial review, based on the impact and objects of that scrutiny, the question whether strict scrutiny applies to any case of differential treatment on the basis of race is much more controversial, as the Bakke case highlighted. The whole discussion hinges on the exact meaning of equality. In logic, the [=] sign is equivalent to the copula is, and it can be understood in two ways. First, it is a statement of existence, and it connects a subject ( $\mathrm{S}$ ) and a predicate $(\mathrm{P})$, and this is the general form of propositions that describe objects of the world or states of affairs. However, propositions can also be analytic, in which case they are tautological, identical, and do not contain any information about the world of reference; they only describe themselves. On that basis, the $[=]$ sign has no meaning of its own, but it has implications in law because it is closely associated with theories in which justice plays a central part. For the Court in Bakke, equality means that there should be no distinct treatment of individuals on the basis of race; one individual shares the same feature with all the others, and that entails having the same rights that are equally and uniformly protected by the Constitution. We may call this an essentialist view. On this basis, the existence of minorities is contingent because their existence may fluctuate with time; thus, it would be dangerous to attribute to one (or several) group(s) a privileged status by means of discriminatory programs, because, if we take into account the possibility of future demographic changes, that group may itself become the majority; in which case any reparative law in its favour might turn out to be discriminatory against the past majority group. But if we adopt Ricœur's opinion on the importance of time in the shaping of a collective memory, we clearly find that communities have shaped their identity around preferential or discriminatory treatment, a phenomenon that is well-documented in the case of African-American history. Time leaves traces that are remembered and transmitted from generation to generation in such a way that pure equal treatment cannot be an appropriate response.

The idea that time is synonymous with progress is the direct heir to the Enlightenment, a view that is both optimistic and abstract. Identity, in that case, is rather formal, mathematical in its definition, and its semanticism is somehow merged with that of equality, because the focus for interpretation is general and universal. If it negated the existence of groups in the eye of the law, the Court's view would run counter to history and sociology while trying to come to terms with its consequences. According to social science, identity is always shaped by the existence of antagonistic communities, an idea which is reflected in the successive rulings that have helped define the paradigm of race in the judicial arena. Indeed, major changes in the legal interpretation of "equality" 
have taken place since Plessy, and have mostly hinged on the idea of "togetherness" as opposed to "separation," but it is remarkable that the existence of groups has always been present in the background. In Plessy, the Court contended that laws mandating that the races be "separate but equal" was constitutional; in Brown, the doctrine was reversed to races being considered as living "together and equal," which, semantically, comes much closer to the constitutional ideal of equality, while it does not address the issue of the existence of groups and communities based on race, and how they should interact within a constitutional framework that upholds equality. In Bakke, however, there has been a shift in the definition of racial relations; individuals should compete against one another for a place in higher education, regardless of color or origin, while the promotion of hitherto minorities was considered as conforming to the purpose of the Constitution (Regents of the University of California v. Bakke 438 US 265 1978: 314-316), ${ }^{24}$ which is logically puzzling. One way of solving this paradox is to consider the Court's view as an attempt to dissociate the concept of race from that of group by stating that race should be one factor to take into account in admissions to law or medical schools, but only as one among a variety of criteria, that should equally apply to individuals. Thus, it is possible to see the ruling as a contribution to the emergence of a color-blind society that would achieve the ideal of togetherness enshrined in the Constitution. However, resorting to strict scrutiny seems to underline the paradox of race, and its paradigmatic status in US constitutional history; indeed, it restricts the impact of legislation in racial matters for historical reasons, while government may elect to take strong incentive measures, like affirmative action, with the same aim, and for identical reasons. Incidentally, if the Supreme Court's view prevails over government-sponsored affirmative action programs, it would, in the long term, prepare for the abandonment of the three-tier standard of scrutiny, should the ideal of color-blindness be achieved. If that was the case, it would demand a different approach to the interpretation of Equal Protection, but this speculation remains entirely hypothetical for one essential reason: the legal language game operates on its own terms, and it does not, or cannot, shape the entire US society, because the latter is based on a strong feeling of community and separate identities in terms of religion, culture, race and origin. Conversely, claiming that society exerts some controlling influence on the law is equally valid, because courts do take context into account when adjudicating a case. So, the reasonable question to ask is not whether a law that gives equal opportunities to a racial group by means of preferential treatment is required by fairness and justice, but whether it is incompatible with it.

\section{The "Mortal Question" of Equal Protection}

The heading of this paragraph is borrowed from philosopher Thomas Nagel, whose collection of essays, published under the title Mortal Questions (1979), ${ }^{25}$ discusses a series of ethical issues, including the issue of equality in chapters 7 ("The Policy of Preference") and 8 ("Equality"). In his preface, Nagel sets the objective of his analysis:

Simplicity and elegance are never reasons to think that a philosophical theory is true: on the contrary, they are usually grounds for thinking it false. Given a knockdown argument for an intuitively unacceptable conclusion, one should assume there is probably something wrong with the argument that one cannot detect-though it is also possible that the source of the intuition has been misidentified. If arguments or systematic theoretical considerations lead to results that seem intuitively not to make sense, or if a neat solution to a problem does not 
remove the conviction that some question is unreal leaves us still wanting to ask it, then something is wrong with the argument and more work needs to be done. Often the problem has to be reformulated, because an adequate answer to the original formulation fails to make the sense of the problem disappear. (Nagel $\mathrm{x}$-xi)

21 Accordingly, the ideal form of philosophy is investigative, its purpose is to strive to find answers by asking relevant questions. In Nagel's view, philosophy is an activity, just like language in Wittgenstein's opinion, but making sense of a problem can often be summed up in its identification, and not its correct (or incorrect) interpretation (Wittgenstein 1953: 33), because it is extremely hazardous to establish what a true or a false statement or opinion is. When applied to Equal Protection as the Court interpreted it in Bakke, it is clear that the problem concerns not only the method, the legal approach adopted by supporters and opponents of affirmative action policies, but also the substance of the argument. In The Policy of Preference, Nagel chooses not to discuss the legal aspect of the issue but its moral implications in terms of justice, an area that overlaps and exceeds the scope of the judicial language game. The main issue is whether or not preferential treatment in favour of a member of a previously discriminated community is fair and just, and articulating such an idea is the result of a long, non-linear process (Nagel 91). It begins with the realisation that institutional discrimination is unacceptable, which generates self-conscious efforts to combat it, even if its existence is visible in many ways. That racial discrimination survives in spite of the law shows that it has been internalized in the course of history and of social development; if de jure segregation has disappeared, de facto discrimination is still visible among those who were formerly stigmatized by the law. Among those people, distinctions should be made between the direct victims of discrimination and their descendants, who may also feel that society does not treat them fairly on inherited racial grounds. Nagel argues that society should examine the existence of perceived discrimination, especially if it is supported by statistics and figures, and determine whether it is just the consequence of an otherwise liberal and unequal society, or if it is the result of a deliberately unfair treatment of racial minorities (Nagel 93). One is left with an alternative: either to decide that merit alone will determine access to socially and financially attractive positions, or to tilt the balance in favor of the affected groups and introduce a compensatory element by means of affirmative action programs. Then again, depending on one's opinion, this should lead to a discussion on the desirability of such programs because a better representation of minorities in higher education is positive in terms of social utility and efficiency. Nagel then insists on the fact that this is a question of opinion and deliberate choice, that there is nothing clear and evident about it in terms of justice because the concept of justice itself is blurred. It is a matter of perception, the workings of memory and the manner in which political ideology sets its standards and goals for what it considers a "just" society (Nagel 97-99). Having described the logical conundrum of the policy of preference, and the impossibility of deciding if it is required by justice, Nagel (101) proceeds to examine whether it is incompatible with it. Accordingly, upholding the differential treatment of minorities with a view to giving equal opportunities to groups previously discriminated against may create adverse effects on otherwise qualified members of the majority (which is the issue in Bakke) but could be justified in terms of utility. ${ }^{26}$ If this ends up providing better access to health, education and the law for under-represented communities, while the self-esteem of white male applicants is not seriously and insidiously endangered, then this benefits society as a whole (Nagel 103). By broadening the 
perspective on equal protection, it becomes clear that the application of the rules of the legal language game is justified within its boundaries, but not if we consider the social fabric it has shaped in the course of history. Thus, interferences between overlapping language games would be at the root of controversies in equal protection. Now the question is to find a way of reconciling the apparent discordance that the notion of the language game seems to convey. Indeed, for the sake of consistency in society and in the legal system, there should be at least one common ground on which language games emerge and add complexity to all issues of meaning and truth-value that would find its justification in what binds humans together and conditions their social interaction. One possibility would be to resort to what Wittgenstein called "forms of life."

\section{Equal Protection and the "Form of life"}

If formal logic cannot provide any sustainable explanation for the diversity of concrete, everyday situations and their correlated perception, ${ }^{27}$ there is at least one form of experience that would synthesize it, a concept that Wittgenstein calls Lebensform ("form of life") ${ }^{28}$. The word itself is not given a clear-cut definition; it refers to what conditions reactions and capacities which are hard-wired in the human brain, as well as to the social and cultural conventions that are the consequences of such capacities. For Wittgenstein, the form of life is a framework for behaviour and conduct in which rules are followed because this is the natural thing to do. Therefore, language emerges as a coherent whole out of a stable and regular form of life, and the infinite number of language games that it generates can only be understood and followed in reference to that form of life (Wittgenstein 1958: 86). Because the latter creates the conditions for a social and intellectual consensus on the description of phenomena-language being the most fundamental of them-it can be identified with the truth-value of propositional logic except that it differs greatly in substance (ibid. 88). Applied to Equal Protection, this statement means that language games are autonomous, they set up their rules in such a way that they can be traced back to the form of life that has enabled them to flourish. It may lead us to conclude that the conventional nature of the law is somehow congenial to human nature itself, but also that it is engaged in a network of games that influence each other in many respects. Thus, the ranking of relevant criteria in constitutional adjudication can be the result of those interactions, which may vary with time and circumstances. The predominance of rules of interpretation derives as much from internal considerations (like methods and traditions) as from outside influences, like political or social theories, or even history in the way it shapes collective memory. The focus has therefore shifted from objective rule-following to accommodation with a variety of experiences that have an equal claim to legitimacy. This analysis should give coherence to the history of the interpretation of the Equal Protection Clause, while underlining the impossibility of finding the most adequate judicial response to the social problems entailed by racial discrimination. It can also be seen as an attempt to dissolve the apparent inconsistencies that have accompanied the Supreme Court rulings in connection with this thorny issue, and one remarkable attempt at conciliating the requirements of law and of justice within the "form of life" of American society in its political dimension can be found in the decision of the Court of Appeals for the Sixth Circuit in Coalition to Defend Affirmative Action v. Regents of the University of Michigan (2011). The issue concerns the constitutionality, under the Equal Protection Clause, of a "successful voter-initiated amendment to the Michigan 
constitution" prohibiting "Michigan's public colleges and universities from granting, according to the text of the amendment (Michigan Constitution, art.1, \$26) 'preferential treatment to [...] any individual or group on the basis of race, sex, color, ethnicity, or national origin."' (\$26(2)). The Appeal Court's approach was to examine the facts in the light of the fair political process of the Equal Protection Clause, which prevents state governments from altering the political structure of the State in a way that would impose an impermissible burden on minorities, by securing the vote of the majority in matters that would, in all likelihood, put them in an electorally-sanctioned unequal position. For the Court, this would amount to the perversion of the very notion of democracy. The Equal Protection Clause "guarantees racial minorities the right to full participation in the political life of the community. It is beyond dispute [...] that given racial or ethnic groups may not be denied the franchise, or precluded from entering into the political process in a reliable and meaningful manner" Washington v. Seattle Sch. Dist. No. 1, 458 US 457, 467, 102 S.Ct. 3187, 73 L.Ed.2d 896 (1982). But the Equal Protection Clause reaches even further, prohibiting "a political structure that treats all individuals as equals, yet more subtly distorts governmental processes in such a way as to place special burdens on the ability of minority groups to achieve beneficial legislation. [...] The State may no more disadvantage any particular group by making it more difficult to enact legislation in its behalf than it may dilute any person's vote or give any group a smaller representation than another of comparable size" Hunter v. Erickson, 393 US 385, 393, 89 S.Ct. 557, 21 L.Ed.2d 616 (1969).

The Supreme Court's statements in Hunter and Seattle emphasize that equal protection of the laws is more than a guarantee of equal treatment under existing law. It is also a guarantee that minority groups may meaningfully participate in the process of creating these laws and the majority may not manipulate the channels of change so as to place unique burdens on issues of importance to them. In effect, the political-process doctrine hews to the unremarkable notion that when two competitors are running a race, one may not require the other to run twice as far or to scale obstacles not present in the first runner's course. Ensuring the fairness of the political process is particularly important because an electoral minority is disadvantaged in its attempts to pass legislation; this is especially true of "discrete and insular minorities," who face unique additional hurdles..$^{29}$ This extract from the ruling echoes the words of President Lyndon Johnson in his 1965 Commencement Address at Harvard University, in which he defines affirmative action as the endeavor to give equal opportunities to racial minorities: "We seek not just freedom but opportunity-not just legal equity but human ability-not just equality as a right and a theory, but equality as a fact and as a result." (Johnson, emphasis added) What is even more remarkable is the manner in which the Court uses the same famous metaphor of the two runners on the racetrack devised by Johnson to illustrate the way in which centuries of racial discrimination have negatively affected minorities. ${ }^{30}$ However, whereas Lyndon Johnson clearly alludes to existing social injustice that affirmative action aims to combat, while political freedom is taken from granted, ${ }^{31}$ the Sixth Circuit gives a detailed definition of equality within a democratic and political framework (Coalition 619-25). Indeed the Civil Rights era motto of "One man, one vote" which insists on the political equality among individuals in the political process, must be supplemented by a thorough consideration of the place of groups in the voting process in such a way as to qualify the preponderance and scope of a majority vote. In that perspective, it is fallacious to argue that the sum of minority voters would exceed in numbers the majority group, ${ }^{32}$ as the Equal Protection Clause speaks of the protection 
of insular groups. This remark points to the necessity to see equality as a multi-faceted concept the dimensions of which must necessarily coexist in society. It can then be reasonably asserted that the form of life spoken of by Wittgenstein is the converging point of otherwise diverging language games, interests, and discourse. It constitutes the environment that nurtures language games and their rules on the one hand, and their metaphoric interactions that are shaped so as to form "family resemblances" (Wittgenstein 1953: 32), on the other hand. Supreme Court rulings in matters of Equal Protection can only mirror the complexity of those interactions and changing focus points.

\section{Conclusion}

Behind the controversies generated by the Supreme Court's attempts at giving a sustainable interpretation of the Equal Protection Clause lies a deeper quest for judicial truth, a truth that seems to elude formal logic, as well as individual and collective experience. It cannot be equated to the sole narrative structure of judgments, and it cannot dissolve the competing social claims that the constitutional text has embodied and generated at the same time. The paradox of truth lies in the fact that it is an absolute necessity envisaged as something particular, because it is a powerful but elusive ingredient of language. To ask whether legal interpretation is a linguistic fallacy is not to deny this indissoluble connection between truth and language, but to state that it does not stand the test of interpretation without highlighting its many contradictions, diffractions and impossibilities. It may also open new perspectives in the analysis of judicial discourse by focusing on the social shaping of legal concepts; the latter can be envisaged as elements of a language game whose rules originate, not in words themselves, and not in a unique connection with its external reference, but as the result of a narrative, metaphorical and over-inclusive construction. From that perspective, the language of law may be considered as a world in its own terms, yet firmly anchored in its social environment. Such a view would highlight the normative importance of legal interpretation while showing the influences to which it is subjected, which could validly generate competing claims that are worthy of future consideration.

\section{BIBLIOGRAPHY}

Aristotle. The Art of Rhetoric. Trans. Hugh Lawson-Tancred. London: Penguin Books, 1991.

Aristotle. Poetics. Trans. Gerald Frank Else. Ann Arbour: U. of Michigan P., 1987.

Arulanantham Ahilan. "Breaking the Rules? Wittgenstein and Legal Realism." Yale Law Journal 107.6 (1998): 1853-1884. https://digitalcommons.law.yale.edu/ylj/vol107/iss6/4/ 
Bix, Brian. “The Application (and Rules-Application) of Wittgenstein's Rule-Following Considerations to Legal Theory." In Wittgenstein and Legal Theory. Ed. Dennis Patterson. Boulder: Westview Press, 1992. 209-223.

Dworkin, Ronald. Law's Empire. Harvard: The Belknap Press, 1986.

Engelmann, Paul. Letters from Ludwig Wittgenstein, with a Memoir. Oxford: Basil Blackwell, 1967.

Finkelstein, David. “How to Do Things with Wittgenstein: The Relevance of Wittgenstein's Later Philosophy to the Philosophy of Law." American Journal of Jurisprudence. Oxford: Oxford UP, 2010. 647-675.

Fiss, Owen. “Objectivity and Interpretation.” Stanford Law Review 34 (1982): 742-3. https:// digitalcommons.law.yale.edu/fss_papers/1217/

Frege, Gottlob. “Über Sinn und Bedeutung." Zeitschrift für Philosophie und Philosophische Kritik 100 (1892): 25-50. http://www.deutschestextarchiv.de/book/show/frege_sinn_1892

Jakobson, Roman. “On Linguistics and Poetics.” In Language and Literature. Eds. Krystyna Pomorska and Stephen Rudy. Cambridge: The Belknap Press, 1987. 62-94.

Johnson, Lyndon B. “Commencement Address at Howard University: To Fulfill These Rights”, LBJ Presidential Library, 1965. [archive : https://web.archive.org/web/20160322112750/http:// www.lbjlib.utexas.edu/johnson/archives.hom/speeches.hom/650604.asp]

Kay, Richard S. "Original Intention and Public Meaning in Constitutional Interpretation." Northwestern University Law Review (2008). http://ssrn.com/abstract=1259867.

McGuinness, Brian ed. Wittgenstein in Cambridge: Letters and Documents 1911-1951. Oxford: Basil Blackwell Ltd, 2008.

Markell, Bruce A. "Bewitched by Language: Wittgenstein and the Practice of Law." Pepperdine Law Review 32.4 (2005): 801-845. http://digitalcommons.pepperdine.edu/plr/vol32/iss4/4

Nagel, Thomas. Mortal Questions. Cambridge: Cambridge UP, 1979.

Nagel, Thomas. "John Rawls and Affirmative Action." Journal of Blacks in Higher Education 39 (Spring 2003): 82-4. DOI: 10.2307/3134387

Ricœur, Paul. La Métaphore vive. Paris: Seuil, 1975.

Ricœur, Paul. Temps et récit 1. L'Intrigue et le récit historique. Paris: Seuil, 1983.

Ricœur, Paul. Temps et récit 3. Le Temps raconté. Paris: Seuil, 1985.

Shawver, Lois. Commentary on Philosophical Investigations. [s.d.] http://users.rcn.com/rathbone/ lw81-88c.htm

Wittgenstein, Ludwig. Tractatus Logico-Philosophicus. Trans. Charles Kay Ogden. London: Routledge, 1922.

Wittgenstein, Ludwig. Philosophical Investigations. Trans. Gertrude Ascombe. Oxford: Basil Blackwell Ltd, 1958.

\section{Cases cited}

Bolling v. Sharpe 347 US 497 (1954).

Brown v. Board. of Education of Topeka 347 US 483 (1954). 
Coalition to Defend Affirmative Action, Integration and Immigrant Rights and Fight for Equality By Any Means Necessary v. Regents of University of Michigan, 652 F.3d 607 (6th Cir. 2012) (currently on appeal to the US Supreme Court sub nom. Schuette v. Coalition to Def. Affirm. Action No. 12-682).

Darthmouth Coll. v. Woodward, 17 US 518 (1819).

Hall v. De Cuir, 95 US 485 (1877).

Louisville N.O. \& T. Ry. Co. v. State, 133 US 587, 10 Sup. Ct. 348 (1890).

Minneapolis \& St. Louis Railroad v. Beckwith 129 US 26 (1889).

Munn v. Illinois 94 US 113 (1877).

Pacific Gas \& Electricity v. Public. Utilities of the Comm'n of California, 475 US 1 (1986).

Paul v. Virginia 75 US (8 Wall) 168 (1869).

The Slaughterhouse Cases 83 US 36 (1873).

Plessy v. Ferguson 163 US 537 (1896).

Railroad Co. v. Brown, 17 Wall. 445 (1873).

Railroad Tax Cases (1882).

Regents of the University of California v. Bakke 438 US 265 (1978).

Roberts v. City of Boston, 5 Cush. 198 (1850).

San Mateo County v. S. Pacific R.R., 116 US 138 (1885).

Santa Clara County v. So. Pacific Railroad 118 US 394 (1886).

State v. Gibson, 36 Ind. 389 (1871).

Strauder v. West Virginia 100 US 303 (1880).

The Slaughterhouse Cases 83 US 36 (1873).

United States v. Carolene Prod. Co., 304 US 144 (1938).

\section{NOTES}

1. Reference is made up of all the contextual, extra-linguistic elements against which the contents of a proposition will be tested. Its role is to attribute a truth-value to those propositions by reference to an existing state-of-affairs. For instance, the statement "John McCain is the $44^{\text {th }}$ President of the United States" is false by reference to the historical context we live in.

2. Verbal statements are not necessarily propositions. Commands or questions, for instance, are not propositions. The latter are considered as the bearers of truth and falsity in connection with reference, irrespective of the natural language used to express them.

3. "Here the term 'language game' is meant to bring into prominence the fact that the speaking of language is part of an activity, or a form of life [...] It is interesting to compare the multiplicity of the tools in language and of the ways they are used, the multiplicity of kinds of word and sentence, with what logicians have said about the structure of language" (Wittgenstein 1958: 24).

4. The main point of his argument is that real objects (the reference) may be designated by several signs (words, groups of words, verbal expressions) and their sense will thus differ from one another (the planet Venus, which is visible from the Earth, is designated be the expressions "Morning Star" or "Evening Star"; different designations provide different meaning and 
information about the reference, and it would be wrong to assume that Morning Star = Evening Star in the same way as we may posit $a=b$ ).

5. Similar statements can be found at $26,32,39$.

6. This word translates the German "meinen," which clearly refers to what the speaker has in mind when making a statement.

7. Fit, according to Dworkin, describes a harmonious relation between legal interpretation and the law's guiding principles.

8. 5 US 137 (1803) : "[I]t is emphatically the province and duty of the judicial department to say what the law is [...] So, if a law be in opposition to the constitution; if both the law and the constitution apply to a particular case, so that the court must either decide that case conformably to the law, disregarding the constitution; or conformably to the constitution, disregarding the law; the court must determine which of these conflicting rules governs the case. This is of the very essence of judicial duty. If then, the courts are to regard the constitution, and the constitution is superior to any ordinary act of the legislature, the constitution, and not such an ordinary act, must govern the case to which they both apply. Those, then, who controvert the principle that the constitution is to be considered, in court, as a paramount law, are reduced to the necessity of maintaining that courts must close their eyes to the constitution, and see only the law. This doctrine would subvert the very foundation of all written constitutions" (my emphasis).

9. "[T]he Constitution is no different from a poem or any legal document. Generality and comprehensiveness are features of any text. Though the Constitution may be more general and comprehend more than a sonnet or a contract, it is comparable in this regard to an epic poem or some national statures. [...] It should also be understood that generality and comprehensiveness do not discourage interpretation but are the very qualities that usually provoke it."

10. See also Shawver (online). This paragraph suggests, according to her, that precision is not always better than imprecision. Indeed, fixing meaning often results in its disappearance.

11. References are to the original French edition.

12. In San Mateo County v. S. Pacific R.R., 116 US 138 (1885), the argument that corporations were "persons" within the meaning of the Fourteenth Amendment was heard for the first time, even if the Court did not rule on that particular issue.

13. Pacific Gas \& Elec. v. Pub. Util. Comm'n of Cali., 475 US 1 (1986), Rehnquist J., dissenting, stated that "(e)xtension of the individual freedom of conscience decisions to business corporations strains the rationale of those cases beyond the breaking point. To ascribe to such artificial entities an 'intellect' or 'mind' for freedom of conscience purposes is to confuse metaphor with reality" (emphasis added). In a way, the very existence of rules is vindicated by this attitude, because what this view expresses is the perception that rules have been violated.

14. The following part relies mainly on Paul Ricœur's analysis of the connection between time and history in the elaboration of meaning and narrative as developed in Temps et récit 3: Le Temps raconté.

15. "The Equal Protection Clause, however, was [...] relegated to decades of relative desuetude while the Due Process Clause flourished as a cornerstone in the Court's defense of property and liberty of contract [...]. In that cause, the Fourteenth Amendment's 'one pervading purpose' was displaced. See e. g., Plessy v. Ferguson, 163 US 537 (1896). It was only as the era of substantive due process came to a close [...] that the Equal Protection Clause began to attain a genuine measure of vitality."

16. "[T] many lands, the reach of the Clause was gradually extended to all ethnic groups seeking protection from official discrimination."

17. "Each [minority] had to struggle [...] to overcome the prejudices not of a monolithic majority, but of a 'majority' composed of various minority groups of whom it was said-perhaps unfairly in many cases-that a shared characteristic was a willingness to disadvantage other groups." 
18. "The guarantees of equal protection," said the Court in Yick Wo, "are universal in their application, to all persons within the territorial jurisdiction, without regard to any differences of race, of color, or of nationality; and the equal protection of the laws is a pledge of the protection of equal laws."

19. "There is no principled basis for deciding which groups would merit 'heightened judicial solicitude' and which would not."

20. "Those whose societal injury is thought to exceed some arbitrary level of tolerability then would be entitled to preferential classifications at the expense of individuals belonging to other groups. Those classifications would be free from exacting judicial scrutiny. As these preferences began to have their desired effect, and the consequences of past discrimination were undone, new judicial rankings would be necessary. The kind of variable sociological and political analysis necessary to produce such rankings simply does not lie within the judicial competence-even if they otherwise were politically feasible and socially desirable."

21. "The object of philosophy is the logical clarification of thoughts. Philosophy is not a theory but an activity. A philosophical work consists essentially of elucidations. The result of philosophy is not a number of 'philosophical propositions,' but to make propositions clear" (Wittgenstein 1922: 77).

22. This case was about the "injurious" labeling and prohibition by the Illinois legislature of the commerce of "filled milk" to other states for health reasons. The appellant claimed that such a decision violated the Due Process Clause of the Fifth Amendment and the Commerce Clause. The Court found that the legislative decision was "presumptively constitutional," so there was no basis for the courts to review it.

23. "There may be narrower scope for operation of the presumption of constitutionality when legislation appears on its face to be within a specific prohibition of the Constitution, such as those of the first ten amendments, which are deemed equally specific when held to be embraced within the Fourteenth [...]. It is unnecessary to consider now whether legislation which restricts those political processes which can ordinarily be expected to bring about repeal of undesirable legislation, is to be subjected to more exacting judicial scrutiny under the general prohibitions of the Fourteenth Amendment than are most other types of legislation. Nor need we inquire whether similar considerations enter into the review of statutes directed at particular religious [...] or national [...] or racial minorities [...]: whether prejudice against discrete and insular minorities may be a special condition, which tends seriously to curtail the operation of those political processes ordinarily to be relied upon to protect minorities, and which may call for a correspondingly more searching judicial inquiry" (emphasis added).

24. "Ethnic diversity, however, is only one element in a range of factors a university properly may consider in attaining the goal of a heterogeneous student body" (316). Referring to the Harvard College program: "In such an admissions program, race or ethnic background may be deemed a 'plus' in a particular applicant's file, yet it does not insulate the individual from comparison with all other candidates for the available seats. The file of a particular black applicant may be examined for his potential contribution to diversity without the factor of race being decisive when compared, for example, with that of an applicant identified as an ItalianAmerican if the latter is thought to exhibit qualities more likely to promote beneficial educational pluralism. Such qualities could include exceptional personal talents, unique work or service experience, leadership potential, maturity, demonstrated compassion, a history of overcoming disadvantage, ability to communicate with the poor, or other qualifications deemed important. In short, an admissions program operated in this way is flexible enough to consider all pertinent elements of diversity in light of the particular qualifications of each applicant, and to place them on the same footing for consideration, although not necessarily according them the same weight" (Powell J.). 
25. Thomas Nagel is an American philosopher, currently University Professor of Philosophy and Law at New York University where he has taught since 1980. His main areas of philosophical interest are philosophy of mind, political philosophy and ethics. His $\mathrm{PhD}$ was supervised by John Rawls, whose theory of justice he discusses in some of his most influential books, notably The Possibility of Altruism (1970, reprinted 1978), Equality and Partiality (1991), and in his article "John Rawls and Affirmative Action" (Nagel 2003).

26. By which we mean the utilitarian concept, based on the calculus of average that defines the common good. Here, Nagel uses this notion in a paradoxical manner: social utility may exist, irrespective of the sum of the interests of the majority. In fact, the purposive feature of utilitarianism is gauged against different time scales: the short term vision of justice, which states that racial preferences are overridden by merit, and long term views stating that Equal Protection is an ongoing process that includes social equality, another facet of justice.

27. Because, contrary to what Wittgenstein had attempted to find in his Tractatus, there is no such a thing as the essence of language.

28. This word refers to any type of human interaction and social organisation.

29. Coalition to Defend Affirmative Action, 701 F.3d 474 (Cole C.J.). See also Cf. United States v. Carolene Prods. Co., 304 US 144, 152 n. 4, 58 S.Ct. 778, 82 L.Ed. 1234 (1938).

30. Compare id., ("You do not take a person who, for years, has been hobbled by chains and liberate him, bring him up to the starting line of a race and then say, 'you are free to compete with all the others,' and still justly believe that you have been completely fair"), with Coalition 652 F.3d at 614

31. "Freedom is the right to share, share fully and equally, in American society-to vote, to hold a job, to enter a public place, to go to school. It is the right to be treated in every part of our national life as a person equal in dignity and promise to all others."

32. Coalition Plaintiffs Supplemental Brief On En Banc Review at 28, Coalition 652 F.3d 607 (2011) (No. 08-1387), 2011 WL 5122713.

\section{ABSTRACTS}

The purpose of this contribution is to provide an insight into the semantics of the Equal Protection clause of the $14^{\text {th }}$ Amendment to the US Constitution as interpreted by the US Supreme Court, how it has been submitted to the vagaries of context and opinions, as the Justices are speakers of the language of law. Legal interpretation will be approached in Part 1 via the exploration of "grammar" and "rules" that have produced contrasted and sometimes ambiguous results as expressed in the Court's decisions, following Ludwig Wittgenstein's concept of the "language game." Such a notion can be seen as the substance that shapes the identity and the memory of groups that have been differently affected by legal decisions. Part 2 will show how the constitutional clause is structured in relation to its meaning and its complex relation with time, as defined by French philosopher Paul Ricœur. Conversely, claiming that society exerts some influence on the law is equally valid. Part 3 will address the question raised by Thomas Nagel, whether a law that gives "equal opportunities" to a group by means of "preferential treatment" is compatible with justice.

L'objectif de cet article est d'analyser le sémantisme de la Clause d'Égale Protection du 14ème Amendement de la Constitution des États-Unis selon l'interprétation qu'en donne la Cour 
Suprême en montrant combien cette interprétation a varié selon le contexte historique et les jugements (opinions) des juges, dépositaires du langage du droit. La première partie sera consacrée à la manière dont l'interprétation en droit a fourni des résultats contrastés et divers grâce à l'étude de sa " grammaire » et de ses « règles » en s'appuyant sur l'analyse du concept wittgensteinien de " jeu de langage ». On peut voir dans cette notion l'ingrédient central qui a forgé l'identité et la mémoire collective de groupes d'individus affectés de différentes façons par les décisions de justice en matière d'égale protection. La deuxième partie s'attachera à montrer que le sens de la clause constitutionnelle est intimement lié aux différentes perceptions subjectives du temps et de la mémoire historiques, tels que ces notions sont définies par Paul Ricœur. A l'inverse, il est tout aussi vrai que la société exerce une très forte influence sur le droit et la loi. C'est ainsi que la troisième partie tentera de répondre à la question, soulevée par Thomas Nagel, de savoir si des mesures de « discrimination positive » sont compatibles avec la notion de justice.

\section{INDEX}

Keywords: rule-following, adjudication, language games, metaphoricity, semanticism, justice, Wittgenstein Ludwig, Ricœur Paul, Constitution of the United States, Supreme Court of the United States, Equal Protection, law

Mots-clés: application de règle, jugement, jeu de langage, métaphorisation, sémantisme, justice, Wittgenstein Ludwig, Ricœur Paul, Constitution américaine, Cour Suprême des États-Unis, égale protection, droit

\section{AUTHOR}

\section{ANNE-MARIE O'CONNELL}

Anne-Marie O'Connell is a Senior Lecturer (Maître de conférences HDR) in legal English and the jurisprudence of Common Law countries at the Département des Langues et Civilisations (Department of Languages and Civilisations) of the University of Toulouse 1 Capitole. After completing a $\mathrm{PhD}$ on the semiotic analysis of Irish mythology as well as a $\mathrm{PhD}$ on the language of being in Martin Heidegger's philosophy, she is currently working on jurisprudence and the didactics of English for legal purposes. She is also a member of the Inter-University Research Laboratory in Foreign Language Teaching \& Learning (LAIRDIL) at the University of Toulouse 3. Contact: Anne-marie.o-connell [at] ut-capitole.fr 